\title{
Detection of Salt Tolerant Gene (TaNIP) and Its Expression in Three Selected Wheat Genotypes Through Plant Breeding Programs Under Salinity Conditions
}

\author{
Ibrahim Ismail Al-Mashhadani, Duha Mysire Majeed, Eman Noaman Ismail, \\ Maysaa Sameer Kadhim
}

Biotechnology Research Center, Al-Nahrain University, Baghdad, Iraq

Email address:

hassanir1955@yahoo.com (I. I. Al-Mashhadani)

\section{To cite this article:}

Ibrahim Ismail Al-Mashhadani, Duha Mysire Majeed, Eman Noaman Ismail, Maysaa Sameer Kadhim. Detection of Salt Tolerant Gene (TaNIP) and Its Expression in Three Selected Wheat Genotypes Through Plant Breeding Programs Under Salinity Conditions. International Journal of Applied Agricultural Sciences. Vol. 2, No. 1, 2016, pp. 12-16. doi: 10.11648/j.ijaas.20160201.12

\begin{abstract}
High soil salinity is a major abiotic stress in plant production worldwide. TaNIP gene was identified and cloned through the gene chip expression analysis of a salt- tolerant wheat mutant RH8706-49 under salt stress. Quantitative reverse transcription - PCR (Q-RT-PCR) was used to detect TaNIP salt tolerant gene and its expression in some selected wheat genotype for salt tolerance through plant breeding programs. The results of qualitative PCR Reaction- cDNA and Quantitative Real-Time PCR showed that the gene band appeared only in the selected genotypes with length $189 \mathrm{bp}$, while this band absent in salt sensitive cultivar (Iraq) under salinity and non-salinity condition. Amount and expression of TaNIP gene to be enhanced under salinity condition only in the selected salt tolerant genotype, and they increased with increasing salt level. Great expression and amount of TaNIP gene was at high salinity level $(20 \mathrm{ds} / \mathrm{m})$. The selected salt tolerant genotype had proximately similar amount and expression of TaNIP gene under all salinity condition, while there had no amounts and expression of this gene in sensitive cultivar (Iraq) therefore according to this gene (TaNIP) there is improvement realized in these selected genotypes for salt tolerance through plant breeding programs.
\end{abstract}

Keyword: Wheat Genotype, Salt Tolerance, TaNIP Gene, Real-Time PCR

\section{Introduction}

Salinity is a big problem in the arid and semi-arid regions. Soil salinity is a major abiotic stress severely affects agricultural productivity. Under high salt stress, plants are affected throughout the growth process from germination to all others growth stages [1]. Induce new salt tolerant genotypes or cultivars are very important to overcome salinity problems and increase productivity of salt affected soils. The tolerances controlled by salt tolerant genes, therefore indentifying these genes and understanding their functions have became the most urgent tasks in agricultural research today. Induce new germplasms with high salt tolerance requires new genetic sources of this character and more efficient techniques [2]. These germplasms are an attractive possibility for exploitation salt affected soils [3].

The development of the technology and biotechnology techniques are important achievement obtained providing a possibility to develop and identify salt tolerant genotypes and genes. During the last decade few researchers isolated number of salt-responsive genes with their characterization $[1,4]$. One of these genes that involved in salt tolerance in wheat is TaSTG with induced expression under salt stress [5] and the gene TaGSK1 which high involved in ions uptake in wheat also detected [6]. Ge et al. [7] indentified salt tolerant gene (TaSTK) in Triticum aestivum L. and this gene is an important role in plants' stress signaling and responses such as high salt, drought and cold. Most of the salt tolerant genes were detected with high expression under salinity conditions in some selected wheat genotypes and cultivars $[8,9,10]$. On other hand [11] identified and cloned salt tolerant gene (TaNIP) through gene chip expression analysis of a salttolerant wheat mutant RH8706+49 under salt stress by using quantitative reverse transcription-PCR (Q-RT-PCR).

The objective of the current study is identifying the salt tolerant gene (TaNIP) and estimation its expression in some selected wheat genotypes $(1 \mathrm{H}, 2 \mathrm{H}, 3 \mathrm{H})$ for salt tolerance 
through plant breeding programs as compared with local cultivar (Iraq) as a salt sensitive under salinity conditions.

\section{Material and Methods}

\subsection{Selected Genotypes Growth}

In this study three selected wheat genotypes for salt tolerance through plant breeding programs and one local cultivar (check cultivar) were used to detect the salt tolerant gene $(T a N I P)$ and its expression under salinity conditions. Seeds of selected genotypes $(1 \mathrm{H}, 2 \mathrm{H}, 3 \mathrm{H})$ and local cultivar (Iraq) were grown in prepared soil salinity at three levels $(0$, $15,20 \mathrm{ds} / \mathrm{m}$ ) under plastic house condition, Five seeds for each pot and for each genotype and cultivars were sown. Three replications for each treatment, and the plants grew under salinity conditions for 45 days from the sowing date. Then leaves sample were taken for RNA extraction.

\subsection{RNA Isolation and cDNA Synthesis}

Total RNA were isolated using Geneaid total RNA purification mini kit (Taiwan) according to the manufacturer's instructions. Isolated RNA was treated with RNase-free DNase-I (Biobasic, Canada) for $20 \mathrm{~min}$ at $37^{\circ} \mathrm{C}$, DNase-I was inactivated at $65^{\circ} \mathrm{C}$ for $10 \mathrm{~min}$. The integrity of the RNA was verified after separation by electrophoresis on a $1.5 \%$ agarose gel containing $0.5 \%(\mathrm{v} / \mathrm{v})$ ethidium bromide. First-strand cDNA was synthesized from $500 \mathrm{ng}$ of total RNA using Reverse Transcription system (Bioneer, Korea) with an oligo- $\mathrm{dT}_{15}$ primer. The reaction solution was used as templates for reverse transcriptase polymerase chain reaction (RT-PCR).

\subsection{TaNIP Gene Amplification}

TaNIP (target gene) and wheat housekeeping B-actin (reference gene) cDNA were amplified using specific primers in table (1). Polymerase chain reaction was initiated with hot start method using the cDNA template on Labnet Thermo cycler (USA). The PCR reaction was carried out at $95^{\circ} \mathrm{C}$ for $5 \mathrm{~min}$ and 40 cycles at $95^{\circ} \mathrm{C}$ for $1 \mathrm{~min}, 58^{\circ} \mathrm{C}$ for $45 \mathrm{~s}$ and $72^{\circ} \mathrm{C}$ for $1 \mathrm{~min}$.

Table 1. Primers used for amplification of TaNIP and actin cDNA sequences.

\begin{tabular}{|c|c|c|c|c|}
\hline Gene & Primer & Sequence5'-3' & Genbank accession number & Reference \\
\hline \multirow{2}{*}{ TaNIP } & Forward & GCATTACGTCCATCTTCGCA & & \multirow{2}{*}{ [11] } \\
\hline & Reverse & CCTCGAAGCGGATGT GGTG & & \\
\hline \multirow{2}{*}{ Actin } & Forward & TGGCACCCGAGGAGCACCCTG & \multirow{2}{*}{ AF326781.1 } & \multirow{2}{*}[12]{} \\
\hline & Reverse & GCGACGTACATGGCAGGAACA & & \\
\hline
\end{tabular}

\subsection{Gene Expression Analysis by Sybr Green-Real-Time (RT-PCR)}

The expression TaNIP gene was examined by SYBR realtime RT-PCR using Exicycler real time PCR (Bioneer, Korea). One step RT-PCR was performed using premix RTPCR qPCR kit (Bioneer, Korea), following the manufacturers protocol. The thermal cycling profile consisted of initial denaturation at $95^{\circ} \mathrm{C}$ for $5 \mathrm{~min}$ and 40 cycles at $95^{\circ} \mathrm{C}$ for 1 min, $58^{\circ} \mathrm{C}$ for $45 \mathrm{~s}$ and $72^{\circ} \mathrm{C}$ for $1 \mathrm{~min}$, followed with melting curve analysis at $60-95^{\circ} \mathrm{C}$ to confirm amplification specificity, the amplified fragments were analyzed by $1.5 \%$ agarose gel electrophoresis containing ethidium bromide. Quantitation of relative expression was determined by the $2^{-}$ $(\Delta \Delta \mathrm{CT})$ method [13]. Each sample was run in triplicate. For estimation of standard curve, online software was used to convert DNA concentration to log copy number (http://www.uri.edu/research/gsc/resources/cndna.html).

\section{Results}

\subsection{Qualitative PCR cDNA}

Using conventional PCR after optimizations of the primers to amplification of the TaNIP salt tolerant gene. After staining with ethidium bromide and visualized under UV light. The results revealed that the size of TaNIP gene amplification gene band was 189 bp according to the DNA ladder (Fig. 1). Gene band of TaNIP was appeared only in the selected genotypes of wheat for salt tolerance under high salinity condition, while this gene band did not appeared in local cultivar (Iraq) and the negative control at the same conditions (Fig. 1). The same results which summarized in (Fig. 1) were observed under non- saline conditions. These results confirmed that the salt tolerant gene (TaNIP) was found only in the genotypes which selected for salt tolerance through plant breeding programs under all conditions, while this gene was absent in the local cultivar (Iraq). Also the results indicated that the size of gene band which appeared in all selected genotypes was similar (189 bp).

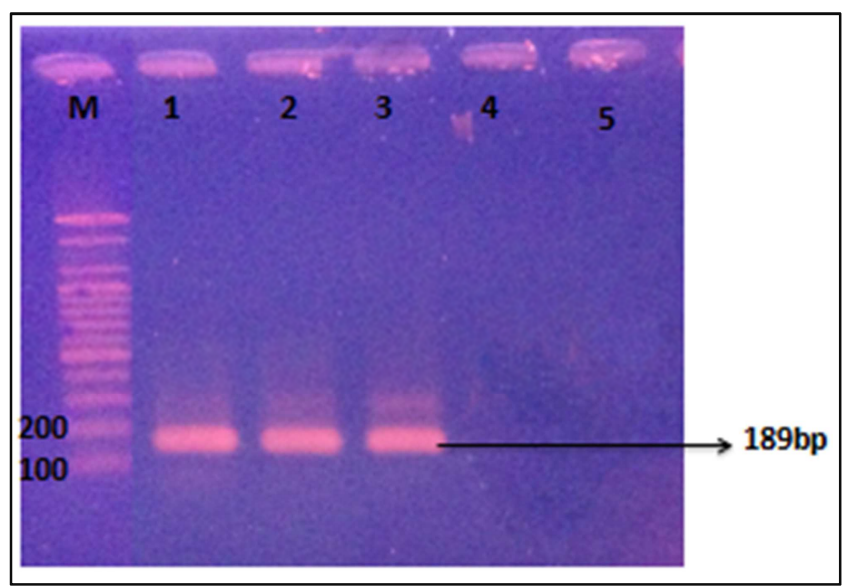

Fig. 1. Ethidium bromide stained agarose electrophoresis (1.5\%) of PCR Product (TaNIP gene) for wheat cultivars. M: Marker (100bp), 1: 1H genotype, 2: $2 H$ genotype, 3: $3 H$ genotype, 4: Iraq cultivar, 5: Negative control. 


\subsection{Quantitative Real-Time PCR}

The amount of a certain gene in the CDNA can be determined by Real-time PCR. This correlated with the threshold cycle $\left(\mathrm{C}_{\mathrm{T}}\right)$ [13].

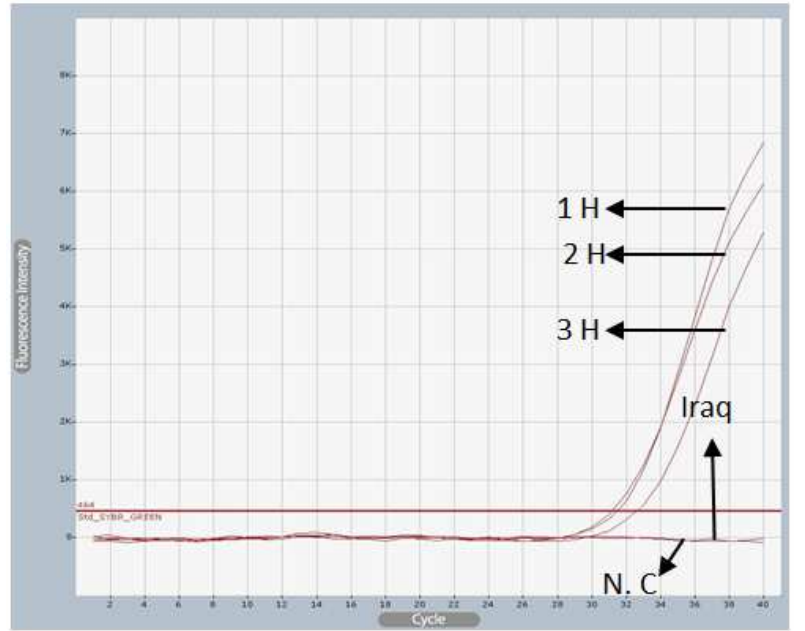

Fig. 2. SYBR Real time PCR amplification curves for TaNIP gene of all wheat $(1 \mathrm{H}, 2 \mathrm{H}, 3 \mathrm{H}$ genotypes and Iraq cultivar).

Table 2. Average of $C_{T}$ values of TaNIP genes SYBR green real time PCR amplification.

\begin{tabular}{lll}
\hline Cultivars & Salt concentration $\mathbf{~ d s} / \mathbf{m}$ & Average \\
\hline \multirow{3}{*}{$1 \mathrm{H}$} & 0 & 31.96 \\
& 15 & 24.06 \\
& 20 & 19.64 \\
$2 \mathrm{H}$ & 0 & 30.68 \\
& 15 & 24.26 \\
& 20 & 20.71 \\
$3 \mathrm{H}$ & 0 & 32.38 \\
& 15 & 25.38 \\
& 20 & 20.43 \\
\multirow{2}{*}{ Iraq } & 0 & ----- \\
& 15 & ----- \\
\hline
\end{tabular}

Estimation of $\mathrm{C}_{\mathrm{T}}$ values depended on the results which summarized in Fig. 2. The average of $C_{T}$ values at each salinity level and each genotype summarized in table 2 . The values of $\mathrm{C}_{\mathrm{T}}$ were negative correlated with the amount of the salt tolerant gene (TaNIP). These results showed that the $\mathrm{C}_{\mathrm{T}}$ values of each selected genotype $(1 \mathrm{H}, 2 \mathrm{H}$, and $3 \mathrm{H})$ decreased with increasing salinity levels, and these indicated that the amount of the TaNIP gene increased with increasing salinity levels. Whilst, the $\mathrm{C}_{\mathrm{T}}$ values of the local cultivar (Iraq) were zero and this mean that the local cultivar does not have any amount from the salt tolerant gene under all conditions (Fig. 2 and Table 2). Also the results showed that there are no differences between the selected genotypes in their amounts of TaNIP gene, but these amounts of each selected genotype differed with increasing salinity levels.

\subsection{Estimation of Gene (TaNIP) Expression}

In order to estimate gene expressions, the efficiency of QPCR was determined by using several decimal dilutions of eluted PCR band. Using the online software DNA copy number to estimate the logarithm of gene copy numbers according to DNA concentration (Fig. 3). Also the amplification of the salt tolerant gene (TaNIP) was done by syber green real-time PCR to estimate the expression of this gene in the selected wheat genotypes $(1 \mathrm{H}, 2 \mathrm{H}$, and $3 \mathrm{H})$ under salinity condition as compared with the salt sensitive (local cultivar) (Table 3 ). the results of the analysis of the real- time PCR showed that TaNIP gene gave expressions to salt tolerance under all salinity conditions, and there are differences in their expression among the salt levels. However, the gene expression increased with increasing salt levels (Table 3). Salt tolerant gene (TaNIP) gave expressions at all salinity levels only in selected genotypes, while there are not expression to this gene in the local cultivar (Iraq) at the some salinity conditions (Fig. 2 and Table 3). At each selected genotype, the gene expression increased with increasing salinity levels, and the heights expression was at the heights salinity level $(20 \mathrm{ds} / \mathrm{m})$ (Table 3$)$ and the lowest expression was at normal condition $(0 \mathrm{ds} / \mathrm{m})$. Also at each salt level, there are not significant differences in gene expression between selected genotypes.

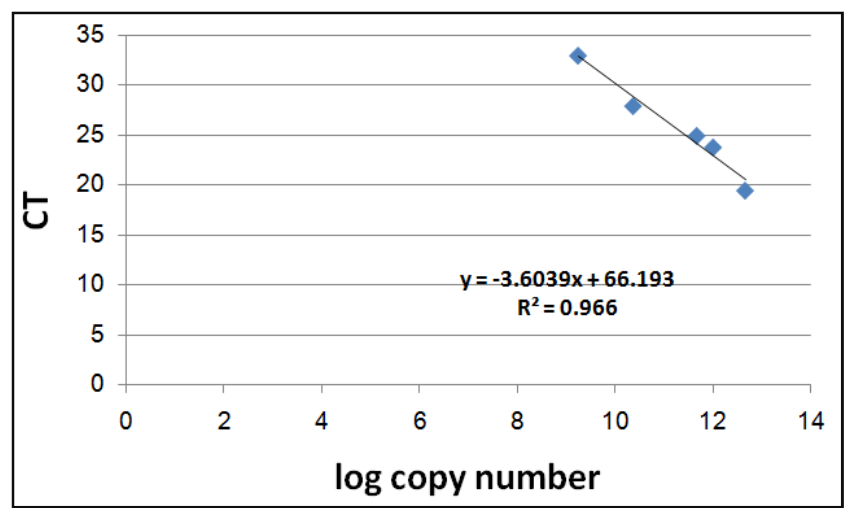

Fig. 3. Standard curve shows slope and $R^{2}$ values to determine the efficiency of PCR reaction for NIP gene amplification.

Table 3. Values of NIP gene expression.

\begin{tabular}{llllc}
\hline Cultivars & Salt concentration ds/m & C T value of $\mathbf{T a N I P}$ gene & CT value of actine gene & Gene expression= $\mathbf{E}^{\mathrm{Ct}(\text { TaNIP) }-\mathrm{Ct} \text { (actine) }}$ \\
\hline \multirow{3}{*}{$1 \mathrm{H}$} & 0 & 31.96 & 23.81 & 0.403 \\
& 15 & 24.06 & 23.62 & 0.952 \\
& 20 & 19.64 & 23.11 & 1.470 \\
& 0 & 30.68 & 23.59 & 0.454 \\
$\mathrm{H}$ & 15 & 24.26 & 23.10 & 0.878 \\
& 20 & 20.71 & 23.36 & 1.342 \\
$3 \mathrm{H}$ & 0 & 32.38 & 23.35 & 0.366 \\
& 15 & 25.38 & 23.42 & 0.804 \\
\hline
\end{tabular}




\begin{tabular}{|c|c|c|c|c|}
\hline Cultivars & Salt concentration $\mathrm{ds} / \mathrm{m}$ & CT value of $T a N I P$ gene & CT value of actine gene & Gene expression $=\mathrm{E}^{\mathrm{Ct}(\mathrm{TaNIP})-\mathrm{Ct} \text { (actine) }}$ \\
\hline \multirow{4}{*}{ Iraq } & 20 & 20.43 & 23.38 & 1.338 \\
\hline & 0 & ------ & ------ & ------ \\
\hline & 15 & ------ & ------ & ------ \\
\hline & 20 & ---- & ------ & ---- \\
\hline
\end{tabular}

\section{Discussion}

In the previous study [11], the TaNIP gene was identified in the salt-tolerant wheat mutant RH8706-49. Also the results indicated that TaNIP expression was induced by salts and this gene could be associated with the salt tolerance pathway in wheat. This gene is one of others salt tolerant genes responsible for inducing salt tolerance in plant through regulation of transmembrane transport, which regulates the cellular ion concentration to some extent, and also through increasing roots growth of TaNIP transgenic plants significantly much higher than those of the wild-Type plants and then increased salt-tolerance of these plants under salinity conditions [11]. They reported that this gene increased the size of vacuoles of mature plant cells to store nutrients and metabolites, which protect cells from potential injury due to salt ions toxic. On the other hand, the vacuoles are important to reduce the injurious effect of salt ions on cytosolic enzymes and keep metabolic reactions normally [14]. This mean that the salt tolerant gene $(T a N I P)$ is important factor for determine salt tolerance degree in plant through exclusion of salt ions from cytoplasm to the vacuoles of the cell to reduce the toxic of these ions. The $\mathrm{K}^{+}$and $\mathrm{Na}^{+}$ levels are important for the health of cell and metabolic process, and the $\mathrm{K}^{+} / \mathrm{Na}^{+}$ratio is an important indicator of plant salt tolerance $[15,16]$. The study that reported by [11] showed that TaNIP over expressing Arabidopsis plants decreased $\mathrm{Na}^{+}$and increased $\mathrm{K}^{+}$accumulations in the leaves as compared with the wild-type plants under salt stress. This mean that this gene increased $\mathrm{K}^{+} / \mathrm{Na}^{+}$ratio in plant under salinity condition that is good indicator for high salt tolerances in plant. Also this gene (TaNIP) increased salt tolerance in plant through the absorption more water quickly and dilute the $\mathrm{Na}^{+}$content in plant to reduce $\mathrm{Na}^{+}$toxic in plants. The result of TaNIP transgenic Arabidopsis plants showed that the salt tolerance was associated with higher $\mathrm{Ca}^{+2}$ content in these plants as compared with the wild-type plants which accumulated low $\mathrm{Ca}^{+2}$ in their leaves [11], because $\mathrm{Ca}^{+2}$ can enhance the activity of AQPS [17] and also plays a crucial role in the salt tolerance signaling pathways [18].

In fact the selected genotypes used in this experiment were derived from plant breeding programs after exposure the seeds and seedling of F2-F7 to 30ds/m drainage water for six cycles of screening and selection. However, the objectives of these breeding programs are to isolate salt tolerant wheat genotypes to examine the possibilities of improving plants to such extent. In the previous studies, these results indicated that there is a strong development in salt tolerance obtained in most selected genotype through these plant breeding programs $[2,3,10]$. The superiority of these selected genotypes $(1 \mathrm{H}, 2 \mathrm{H}$, and $3 \mathrm{H})$ in their salt tolerance may due to the segregation of salt tolerant genes in these selected genotypes plants through the cycles of screening and selection and these genes exhibited expression when grown under high salinity condition. Molecular studies were carried out to detected salt tolerance gene (TaNIP) and estimate their expression in these selected genotypes $(1 \mathrm{H}, 2 \mathrm{H}$, and $3 \mathrm{H})$ of wheat under salinity conditions. This gene was detected in these selected genotypes and gave high expression under high salinity conditions (fig. 1 and table 3 ), which also detected with high expression in salt-tolerant wheat mutant RH8706-49 under salt stress [11], and this gene (TaNIP) produced higher salt tolerance in transgenic Arabidopsis than wild- type plants. These results agreed with the results of this study, so it's found and gave high expression only in the selected genotypes and absent in the local cultivar (Iraq), this reflecting that TaNIP plays an important role in salt-tolerance in selected genotypes. Then this conclusion supported the results of previous studies $[3,10]$ which reported that selected genotypes have high tolerance to salinity. Therefore there is high correlation between TaNIP gene and salt tolerance of these selected genotypes, salt tolerant wheat mutant RH8706-49 and transgenic Arabidopsis under salinity conditions.

The results of this study revealed that the amount and expression of TaNIP gene was similar in all the selected genotypes under high salinity condition, this mean, the salt tolerance degree was also similar in these selected genotypes. Previously, research indicated that the salt tolerance degree in any plant depend on the kind and amount of salt tolerant genes which segregated through cycle of screening and selection [15]. Similarly, [19] reported that the superiority of selected cultivars and genotype in salt tolerance of the local cultivar under high salinity level due to the presence of salt tolerance gene (TaSTK) with high expressions and gene amounts. Therefore, the genetic improvement or advance for salt tolerance is realized through plant breeding programs. The same genetic improvement was realized in the selected cultivar (Dijilla) through this program [20].

The conclusions of these results reveled that the salt tolerant gene $(T a N I P)$ found only in the selected genotypes gave high amount and expression under high salinity levels $(20 \mathrm{ds} / \mathrm{m})$, and there are not significant differences between the selected genotypes in their gene amount and expressions. Also according to the present and previous studies there was a big genetic advance realized in these selected genotypes for salt tolerance through plant breeding programs.

\section{References}

[1] Sairam, R. K. and Tyagi, A. (2004). Physiological and molecular biology of salinity stress tolerance in plants. Curr. Sci. 86(3): 407-421. 
[2] Al-Mishhadani, I. I. H. (2012). Breeding and selection of some Lines of Bread Wheat for salt tolerance. Journal of Agricultural Science and Techbology B. 2(8): 934-939.

[3] Al-Mishhadani, I. I. H.; Abdula, K. H.; Isamil, E. N.; Thahre, Y. D. and Weab, I. A. (2014). Estimation of new wheat genotypes for salt tolerance which induced through plant breeding programs. Journal of Agricultural Science and Techbology B. 4 (2): 150-156.

[4] Tester, K. M. R. and Roy, S. J. (2009). Quantifying the three main components of salinity tolerance in cereals. Plant, Cell and Environment. 32, 237-249.

[5] Wang, W.; Vinocur, B. and Altman, A. (2003) Plant responses to drought, salinity and extreme temperatures: towards genetic engineering for stress tolerance. Planta; 218: 1-14.

[6] Chen, G. P.; Ma, W. S.; Huang, Z. J.; Xu, T.; Xue, Y. B. and Shen, Y. Z. (2003). Isolation and characterization of TaGSK1 involved in wheat salt tolerance. Plant Sci. 165, 1369-1375.

[7] Ge, R-C, Chen, G-P, Zhao, B-C, Shen, Y-Z and Huang, Z-J (2012). Cloning and functional characterization of a wheat serine/threonine kinase gene ( TaSTK) related to saltresistance. Plant Science 173, 55-60.

[8] Ismail, E. N. (2013). Determination of gene expression of salt tolerant gene TaGSK1 in wheat cultivars Triticum aestivum L. Baghdad University.

[9] Majeed, D. M.; Shwkat, M. S. and Sabbah, M. A. (2014). Determination of TaSC salt tolerance gene expression in selected wheat under different salt stresses. Egypt. Acad. J. Biolog. Sci. 5(1): 105-113.

[10] Al-Mishhadani, I. I. H.; Zakariya, B. F.; Ismail, E. N. and Wisam, M. D. (2015). Detection for salt tolerance character in two selected genotypes of wheat. International Journal of Biology. 7(1): 54-60.

[11] Gao, Z.; He, X.; Zhao, B. (2010) Overexpressing a putative aquaporin gene from wheat, TaNIP, enhances salt tolerance in transgenic Arabidopsis. Plant Cell Physiol.; 51(5): 767-775.
[12] Guang Y, Yu F, and Liang D, (2011). Molecular cloning of a novel GSK3/shaggy-like gene from Triticum monococcum L. and its expression in response to salt, drought and other abiotic stresses. Afr. J. Biotechnol. 10 (20): 4065-4071.

[13] Livak K, and Schmittgen T, (2001). Analysis of relative gene expression data using real-time quantitative PCR and the 2(Delta Delta C (T)) method. Methods. 25: 402-408.

[14] Barkla, B. J. and Pantoja, O. (1996) physiology of ion transport across the tonoplast of higher plants. Annu. Rev. Plant physiol. 47: 159-184.

[15] Munns M, (2005). Genes and salt tolerance: bringing them together. New Phytologist; 167: 645-663.

[16] Cuin, T. A.; Betts, S. A.; Chalmandrier, R. and Shabala, S (2008) A root's ability to retain $\mathrm{K}^{+}$correlates with salt tolerance in wheat. J. Exp. Bot.; 59: 2697-2706.

[17] Cabanero, F. J., Martinez-Bellest, M. C. and Teruel, J. A. (2005) new evidence about the relationship between water channel activity and calcium in salinity - stressed pepper plants. Plant physiol. 13: 745-752.

[18] Sheen, j. (1996) $\mathrm{Ca}^{+2}$ dependent protein kinases and stress signal transduction in plants. Science 274: 1900-1902.

[19] Al-Mishhadani, I. I. H. (2015) Estimation of salt tolerance degree in some selected wheat genotypes by using detection of salt tolerant gene (TaSTK) and its expression under salinity conditions. Int. of Appl. Agric. Sci. 1 (2): 31-35.

[20] Al-Mishhadani, I. I. H; ismail, E. N.; Jaddoa, K. A.; Majeed, D. M. and Mohammed, O. A (2015) Estimation of the interaction effect between salinity and growth regulators on salt tolerance of two bread wheat cultivar. Int. of Appl. Agric. Sci. 1 (4): 95-101. 